\title{
ANALISIS KESULITAN PESERTA DIDIK DALAM MENYELESAIKAN SOAL MATEMATIKA DITINJAU DARI PEMAHAMAN KONSEP
}

\author{
Kartini $^{1)}$, Sri Muryaningsih ${ }^{2)}$, Aji Heru Muslim ${ }^{3)}$ \\ ${ }^{1}$ PGSD, Universitas Muhammadiyah Purwokerto \\ Email: kartiniidaa@gmail.com \\ ${ }^{2}$ PGSD, Universitas Muhammadiyah Purwokerto \\ Email: srimuryaningsihump@gmail.com \\ ${ }^{3}$ PGSD, Universitas Muhammadiyah Purwokerto \\ Email: ajiherumuslim@gmail.com
}

\begin{abstract}
Abstrak
Penelitian ini bertujuan untuk mengetahui kesulitan peserta didik dan faktor-faktor penyebab dalam menyelesaikan soal matematika ditinjau dari pemahaman konsep kelas $\mathrm{V}$ SD Negeri Ciberem. Jenis dan pendekatan dalam penelitian ini adalah jenis penelitian deskriptif kualitatif. Adapun teknik pengumpulan data dalam penilitian ini adalah tes, wawancara, dan observasi. Hasil penelitian menunjukkan bahwa pada subyek penelitian kemampuan pemahaman konsep atas mengalami sedikit kesulitan mendefinisikan konsep dan menyelesaikan soal cerita. Pada tingkat kemampuan pemahaman konsep mengalami kesulitan dalam mendefinisikan konsep, menyelesaikan soal cerita, dan operasi hitung. Pada tingkat kemampuan pemahaman konsep bawah mengalami kesulitan mendefinisikan konsep, mengklasifikasikan objek, menyajikan konsep dalam berbagai bentuk representasi, membuat contoh dan non contoh penyangkal, mengaplikasikan konsep atau algoritma pemecahan masalah, dan operasi hitung. Sedangkan faktor-faktor yang menjadi penyebab yaitu faktor minat, motivasi, intelegensi, orang tua, dan guru.
\end{abstract}

Kata Kunci: kesulitan menyelesaikan soal, pemahaman konsep

\begin{abstract}
This research aimed to find out the difficulties of students and the causing factors in solving mathematics questions viewed from the consept understanding on the fifth grade of SD Negeri Ciberem. This was a descriptive qualitative research. The data were collected using test, interview, and observation. The results showed that on the subject of upper concept understanding skill, students had difficulties in defining the concept and solving story questions. On the level of concept understanding skill, students had difficulties in defining the concept, solving questions, and calculating operation. On the level of lower concept understanding skill, students had difficulties in defining the concept, classifying object, presenting the concept in many kinds of representation, making examples and non-examples of denial, applying the concept or algorithm of problem solving, and calculating operation. Meanwhile, the causing factors were the factors of interest, motivation, intellegence, parents, and teacher.
\end{abstract}

Keyword : Problem Solving Difficulties, Concept Understanding 


\section{PENDAHULUAN}

Matematika merupakan kegiatan pembelajaran yang dilakukan dengan cara berhitung. Dari proses pembelajaran yang identik dengan cara berhitung ini sangat bermanfaat bagi kehidupan sehari-hari dari bidang kehidupan apa pun. Menurut Hasratuddin (2013), matematika adalah suatu cara untuk menemukan jawaban terhadap masalah yang dihadapi manusia; cara menggunakan informasi, menggunakan bentuk dan ukuran, menggunakan pengetahuan tentang menghitung, dan yang paling penting adalah memikirkan dalam diri manusia itu sendiri dalam melihat dan menggunakan hubungan-hubungan. Matematika sangat penting bagi manusia dan harus dipelajari dikarenakan tanpa disadari aktivitas sehari-hari pasti menggunakan matematika. Mempelajari matematika ternyata merupakan sebuah hal yang dapat dilakukan dengan mudah. Hal ini dapat dilihat dari hasil belajar peserta didik pada mata pelajaran matematika yang secara umum rendah. Matematika dianggap sulit oleh sebagian besar peserta didik. Menurut Puspitasari dkk (2015) banyak siswa yang beranggapan bahwa pelajaran matematika membosankan dan tidak menarik, hal ini disebabkan karena mata pelajaran matematika dirasakan sukar dan rumit.

Hasil belajar rendah dikarenakan kesulitan belajar, salah satu kesulitan belajar yaitu berdampak pada kesulitan dalam menyelesaikan soal. Salah satu SD yang mengalami permasalahan tersebut yaitu SD Negeri Ciberem. Berdasarkan studi penelitian pendahuluan yang dilakukan di SD Negeri Ciberem kelas V dimana guru kelas mengatakan bahwa hasil belajar peserta didik pada mata pelajaran matematika rendah yaitu rata-rata 58,75 dari 32 peserta didik. Pada penelitian pendahuluan, guru kelas V SD Negeri Ciberem selain mengatakan bahwa hasil belajar rendah, beliau juga mengatakan bahwa peserta didik mengeluh kesulitan dalam menyelesaikan soal matematika. Penelitian pendahuluan yang sudah dilakukan dapat diketahui bahwa, kesulitan peserta didik dalam menyelesaikan soal disebabkan oleh tingkat kemampuan yang rendah dalam belajar matematika. Kemampuan peserta didik dalam belajar matematika biasanya sudah terlihat pada setiap tahapan-tahapan dalam belajar matematika. Salah satu tahapan yang sangat penting dalam pembelajaran matematika adalah 
pemahaman konsep. Kesulitan dalam menyelesaikan di kelas V SD Negeri Ciberem akan dilihat dari kemampuan pemahaman konsepnya. Menurut Susanto (2003) mengemukakan bahwa, pemahaman konsep harus dibangun pada setiap belajar matematika dan diharapkan tumbuh kemampuan peserta didik untuk mengkomunikasikan konsep yang telah dipahami dengan baik dan benar. Pemahaman konsep yang rendah mengakibatkan siswa mengalami kesulitan dalam mengerjakan soal. Tingkat pemahaman konsep peserta didik yang rendah merupakan salah satu penyebab dalam sebuah keberhasilan belajar peserta didik.

Selain tingkat pemahaman konsep, berdasarkan hasil penelitian pendahuluan di SD Negeri Ciberem guru kelas V mengatakan bahwa kemampuan peserta didik yang berbeda-beda, sehingga guru sulit untuk menyesuaikan antara peserta didik dengan tingkat kecerdasan yang tinggi dan rendah. Peran guru dalam mengatasi permasalahan ini sangat penting agar permasalahan diminimalisir. Dari hasil wawancara ini dapat diketahui bahwa kesulitan siswa disebabkan oleh faktor-faktor yang menghambat peserta didik dalam belajar dan pada akhirnya akan mengalami kesulitan dalam menyelesaikan soal. Maka dari itu, penting untuk mengetahui faktor-faktor yang menyebabkan peserta didik mengalami kesulitan dalam mengerjakan soal matematika kelas V SD Negeri Ciberem.

\section{METODE PENELITIAN}

Penelitian merupakan penelitian kualitatif. Menurut Moleong (2005) penelitian kualitatif adalah penelitian yang bermaksud untuk memahami fenomena tentang apa yang dialami oleh subjek penelitian misalnya perilaku, persepsi, motivasi, tindakan, dll., secara holistik, dan dengan deskripsi dalam bentuk kata-kata dan bahasa, pada suatu konteks khusus yang alamiah dan dengan memanfaatkan berbagai metode alamiah. Peneliti melakukan penelitian di SD Negeri Ciberem. SD Negeri Ciberem beralamat di Jalan Raya Ciberem, Kelurahan Ciberem, Kecamatan Sumbang, Kabupaten Banyumas. Penelitian ini akan dilakukan pada bulan April- Mei 2019.

Instrumen penelitian yang digunakan yaitu peneliti. Penelitian ini juga menggunakan instrumen lainnya untuk mendukung penelitian dalam memperoleh 
data yang lebih dalam dan akurat. Instrumen pendukung tersebut adalah tes, observasi, wawancara. Subyek penelitian ini yaitu guru, peserta didik, dan orang tua. Subyek penelitian yang utama adalah peserta didik, sedangkan subyek penelitian kedua yaitu guru, diikarenakan guru yang mengetahui permasalahan yang ada di kelas. Peran subyek penelitian orang tua disini sebagai pendukung.

Teknik pengumpulan data yaitu tes, wawancara, dan observasi. Tes dalam penelitian ini digunakan untuk mengetahui kesulitan seperti apa yang dialami oleh peserta didik dan mengetahui pemahaman konsep peserta didik dengan materi pengolahan data. Setelah dilakukan tes kemudan diperoleh hasil dan dari hasil tes kemudian dikategorikan kemampuan pemahaman konsep peserta didik. Hasil tes pemahaman konsep matematis peserta didik ada tiga yaitu kategori tingkat pemahaman konsep atas, tingkat pemahaman konsep sedang, dan tingkat pemahaman konsep bawah. Peserta didik yang telah dikategorikan berdasarkan hasil tes kemudian dilakukan analisis dan wawancara untuk memperoleh data mengenai kesulitan peserta didik dalam menyelesaikan soal Matematika.

Penelitian ini menggunakan tes essay dengan soal yang tersusun sesuai dengan indikator pemahaman konsep matematis. Pada penelitian ini uji validitas dilakukan untuk mengetahui apakah butir-butir tes yang telah disusun benar-benar dapat mengungkapkan bagaimana pemahaman konsep matematis peserta didik dalam menyelesaikan soal matematika. Validator yang dipilih adalah satu orang dosen mata kuliah matematika yaitu Bapak Arifin Muslim S.Pd. M.Pd.. Pada penelitian ini uji validitas untuk soal instrumen pemecahan masalah yang digunakan validitas isi.

Teknik analisis data yang digunakan dalam penelitian ini adalah teknik analisis data model Miles dan Huberman. Menurut Sugiyono (2013) aktivitas dalam analisis data, yaitu data reduction, data display, dan conclusion drawing/verification. Masing-masing tahap dapat diuraikan sebagai berikut. 


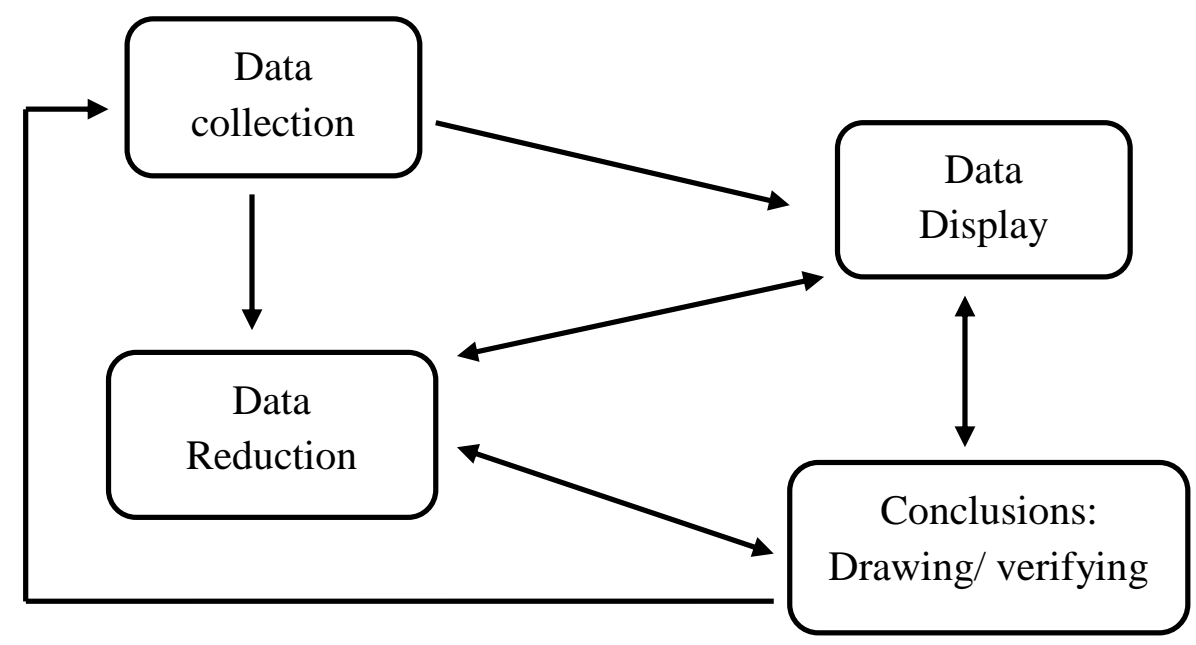

Gambar 1. Analisis Data Model Miles dan Huberman

Penelitian ini menggunakan uji kredibilitas data yaitu triangulasi. Menurut Sugiyono (2013) triangulasi dalam pengujian kredibilitas ini diartikan sebagai pengecekan data dari berbagai sumber dengan berbagai cara dan berbagai waktu. Pada penelitian ini akan menggunakan trianggulasi sumber. Trianggulasih sumber ini digunakan untuk mencari data mengenai faktor yang menjadi penyebab peserta didik kesulitan dalam menyelesaikan soal Matematika dan didukung dengan observasi. Sumber data dalam mencari data mengenai faktor yang menyebabkan peserta didik kesulitan dalam menyelesaikan soal matematika yaitu peserta didik, orang tua, dan guru.

\section{HASIL PENELITIAN DAN PEMBAHASAN}

a. Apa Saja Kesulitan yang Dialami Peserta Didik dalam Menyelesaikan Soal Matematika Ditinjau dari Pemahaman Konsep?

Setelah peserta didik melakukan tes, peneliti mengkategorikan peserta didik kedalam 3 kategori berdasarkan hasil tes yaitu peserta didik dengan kemampuan pemahaman matematis atas, kemampuan pemahaman konsep matematis sedang, dan kemampuan pemahaman konsep bawah. Dari masingmasing kategori dipilih subyek penelitian. Dalam memilih subyek penelitian peneliti meminta pendapat subyek penelitian yang mana yang akan dipilih dari 
masing-masing kategori dan kemudian dilakukan analisis hasil tes dan wawancara.

Peserta didik kemampuan pemahaman konsep atas yang dilakukan melalui tes dan wawancara yaitu pada tahap mendefinisikan konsep secara verbal dan tulisan sedikit mengalami kesulitan dalam menyelesaikan soal. Kesulitan tersebut terlihat pada hasil tes dan wawancara yang menunjukkan peserta didik tidak mampu menyertakan arti dari istilah yang mewakili konsep tersebut. Selain kesulitan dalam mendefinisikan konsep secara verbal dan tulisan, peserta didik kemampuan pemahaman konsep atas juga mengalami sedikit kesulitan dalam menyelesaikan soal cerita, dimana peserta didik AK/PS/SP berdasarkan wawancara mengungkapkan bahwa soal cerita kadang-kadang sulit. Pada indikator lain peserta didik kemampuan pemahaman konsep atas tidak mengalami kesulitan yaitu yaitu pada indikator mengkalsisikasikan objek menurut sifat-sifat tertentu, menyajikan konsep dalam berbagai bentuk representasi, dan membuat contoh dan non contoh penyangkal.

Peserta didik kemampuan pemahaman konsep sedang yang dilakukan melalui tes dan wawancara yaitu pada tahap mendefinisikan konsep secara verbal dan tulisan sedikit mengalami kesulitan dalam menyelesaikan soal. Kesulitan tersebut terlihat pada hasil tes dan wawancara yang menunjukkan peserta didik tidak lengkap dalam menyebutkan konsep dimana peserta didik mengingkat konsep akan tetapi tidak mampu menyertakan arti dari istilah yang mewakili konsep tersebut. Selain kesulitan dalam mendefinisikan konsep secara verbal dan tulisan, peserta didik kemampuan pemahaman konsep atas juga mengalami sedikit kesulitan dalam menyelesaikan soal cerita, dimana peserta didik SN/PS/SP berdasarkan wawancara mengungkapkan bahwa soal cerita tidak sulit jika sudah tahu atau paham. Pendapat SN/PS/SP tersebut menunjukkan bahwa peserta didik tersebut sedikit mengalami kesulitan dalam mengerjakan soal cerita.

Kesulitan lain yang dialami oleh SN/PS/SP yaitu pada soal indikator menyajikan konsep dalam berbagai bentuk representasi. Pada indikator ini 
sebenarnya peserta didik SN/PS/SP mampu menyajikan konsep dalam berbagai bentuk representasi, akan tetapi hasil operasi hitung yang dikerjakan belum benar. Pada indikator lain peserta didik kemampuan pemahaman konsep sedang tidak mengalami kesulitan yaitu yaitu pada indikator mengkalsisikasikan objek menurut sifat-sifat tertentu, menyajikan konsep dalam berbagai bentuk representasi, dan membuat contoh dan non contoh penyangkal.

Peserta didik kemampuan pemahaman konsep bawah yang dilakukan melalui tes dan wawancara yaitu peserta didik RN/PS/SP mengalami kesulitan di setiap indikator pemahaman konsep. Kesulitan yang dialami oleh peserta didik RN/PS/SP meliputi lemahnya kemampuan berpikir abstrak hal ini terlihat pada saat melakukan wawancara, jika peserta didik tidak dihadapkan pada soal atau materi peserta didik tidak dapat menyebutkan konsep dan mengalami kesulitan. Selain itu peserta didik RN/PS/SP mengalami kesulitan dalam mengerjakan soal yang mempunyai proses cukup panjang dalam mengerjakannya. Peserta didik mengalami kesulitan sehingga langkahlangkah yang dikerjakan tidak tepat dan jawaban yang diberikan pun tidak benar dalam perhitungannya. Jawaban peserta didik RN/PS/SP sebagian besar langsung menjawab poinnya tanpa menyertakan langkah-langkah dalam menyelesaikan soal tersebut. Pada saat dilakukan wawancara terlihat bahwa peserta didik RN/PS/SP tidak menjawab pertanyaan secara lisan dengan selesai, peserta didik RN/PS/SP mengungkapkan lupa mengenai materi.

Kesulitan yang dialami oleh peserta didik sebagian besar yaitu dalam mendefinisikan konsep secara verbal dan tulisan. Bahkan dari semua kategori pemahaman konsep matematis mengalami kesulitan tersebut dalam hal ini yaitu AK/PS/SP, SN/PS/SP, dan RN/PS/SP. Peserta didik mengetahui prinsip akan tetapi tidak dapat mengutarakannya Hal ini sesuai dengan pernyataan Coney dalam Abdurahman (2003) yang menyatakan bahwa kesulitan dalam mempelajari konsep yaitu siswa dapat menyatakan suatu prinsip tetapi tidak dapat mengutarakan artinya, dan tidak dapat menerapkan prinsip itu. Dari ketiga jawaban yang diberikan peserta didik menunjukkan bahwa peserta 
didik hanya mengingat intinya saja padahal dalam konsep tersebut terdapat teori yang lengkap.

Kesulitan dalam menyelesaikan soal matematika tentunya dapat disebabkan banyak hal. Salah satunya yaitu peserta didik kurang mampu dalam operasi hitung. Hal ini seperti yang dialami oleh SN/PS/SP dan RN/PS/SP yaitu dalam operasi hitung pembagian masih salah. Hal ini sesuai pendapat Lerner dalam Abdurrahman (2003) yang menyatakan kekeliruan yang dilakukan oleh anak berkesulitan belajar salah satunya yaitu perhitungan. Peserta didik tidak dapat menghitung operasi pembagian salah satunya apabila hasil yang ditemukan ada angka dibelakang koma. Kesulitan lainnya yaitu dalam menyelesaikan soal cerita, hal ini dialami oleh AK/PS/SP, SN/PS/SP, dan RN/PS/SP. Dari hasil wawancara ketiganya mengaku kesulitan dalam menyelesaikan soal cerita dikarenakan berbagai alasan.

Kesulitan lannya yaitu dalam mengingat dalil-dalil matematika. Peserta didik RN/PS/SP mengalami kesulitan dalam mengingat dalil-dalil matematika. Ketika wawancara, RN/PS/SP menjawab peratnyaan dengan tidak lengkap dan diakhirir dengan kata lupa. Hal ini juga selaras dengan pendapat Wood dalam Untari (2013) yang menyatakan bahwa karaktersitik kesulitan peserta didik dalam belajar matematika yaitu tidak sanggup mengngat dalil-dalil matematika. Kesulitan lain yang dialami oleh RN/PS/SP yaitu akan kesulitan jika dihadapkan dengan soal yang membutuhkan daya pikir lebih. Jika peserta didik dihadapkan dengan pertanyaan langsung secara lisan akan mengalami kesulitan. Kesulitan ini selaras dengan pendapat Wood dalam Untari (2013) yang menyatakan karakteristik kesulitan peserta didik dalam belajar matematika salah satunya yaitu lemahnya kemampuan berpikir abstrak.

1.) Apa Saja Faktor yang Menyebabkan Peserta Didik Kesulitan dalam Menyelesaikan Soal Matematika

Kesulitan peserta didik dalam menyelesaikan soal tidak terlepas dari faktor-faktor yang menyebabkan siswa kesulitan. Faktor-faktor yang menyebabkan peserta didik kesulitan dalam menyelesaikan soal matematika dapat disimpulkan bahwa faktor yang berpengaruh adalah 
faktor intern dan ekstern. Faktor intern ini merupakan faktor yang ada pada diri peserta didik yang kaitannya dengan psikologis atau rohani. Menurut Smith dalam Ahmadi dan Supriyono (2013: 79) menyatakan bahwa salah satu faktor intern yang menjadi penyebab kesulitan belajar yaitu karena rohani yang meliputi intelegensi, bakat, motivasi, faktor kesehatan mental, dan tipe-tipe khusus seseorang pelajar. Faktor-faktor yang menjadi penyebab kesulitan peserta didik dalam menyelesaikan soal matematika ini yaitu diri sendiri, dimana peserta didik harus memiliki motivasi dan minat. Mengenai intelegensi pada dasarnya Tuhan sudah memberi tingkat kecerdasan yang berbeda pada setiap mahkluknya, akan tetapi apabila peserta didik semangat dalam belajar dan tekun akan dapat mengatasi masalah kesulitan belajar.

Faktor ekstern yang berpengaruh yaitu orang tua dan guru. Orang tua sangat berpengaruh terutama dalam membangun psikologis anaknya yaitu minat, motivasi, dan rasa kasih sayang dari orang tua. Berdasarkan hasil penelitian, orang tua peserta didik kurang memperhatikan anaknya dalam hal memantau belajar peserta didik di rumah dan memberi kasih sayang berupa perhatian misalnya menanyakan bagaimana belajar di sekolah. Jika perhatian yang diberikan kurang akan menyebabkan psikis anak kurang baik dan berpengaruh terhadap minat dan motivasi anak dalam belajar. Selain berpengaruh ter

Guru sebagai orang tua kedua yaitu di sekolah juga berpengaruh dalam keberhasilan belajar. Berdasarkan wawancara dan observasi aspek yang berkaitan dengan guru yang mempengaruhi kesulitan peserta didik belajar dalam hal ini kesulitan mengerjakan soal matematika yaitu tentang sikap guru. Sesuai pendapat peserta didik sikap guru baik, penyanyang, dan tidak pernah marah. Salah satu sikap guru yaitu sikap tidak pernah marah menjadi faktor penyebab. Peserta didik terkadang tidak dapat membedakan bagaimana cara berkomunikasi dengan guru dan teman. Tidak mampu membedakan cara berkomunikasi dengan guru dan teman 
dapat menyebabkan peserta didik menyepelekan guru dan mengakibatkan peserta didik dengan mudah mengeluh kepada guru.

\section{SIMPULAN}

Berdasarkan hasil analisis data dan pembahasan, maka diperoleh kesimpulan sebagai berikut:

a. Pemahaman konsep matematis di kelas V SD Negeri Ciberem dengan kategori kemampuan pemahaman konsep atas mengalami sedikit kesulitan dalam mendefinisikan konsep secara verbal dan tulisan dan dalam menyelesaikan soal cerita, sedangkan indikator lainnya peserta didik dengan kategori kemampuan pemahaman konsep mampu dan tidak mengalami kesulitan. Pemahaman konsep matematis di kelas V SD Negeri Ciberem kategori pemahaman konsep sedang mengalami kesulitan pada mendefinisikan konsep secara verbal, menyelesaikan soal cerita atau pada indikator mengaplikasikan konsep atau algoritma pemecahan masalah, dan kesulitan dalam berhitung pada indikator menyajikan konsep dalam berbagai bentuk representasi. Pemahaman konsep matematis di kelas V SD Negeri Ciberem dengan kategori kemampuan pemahaman konsep bawah mengalami kesulitan pada semua kategori.

b. Faktor-faktor yang menjadi penyebab peserta didik mengalami kesulitan dalam menyelesaikan soal Matematika yaitu faktor intern dan ekstern. Faktor ini meliputi minat, motivasi, dan intelegensi. Sedangkan faktor ekstern yaitu orang tua dan guru.

\section{DAFTAR PUSTAKA}

Abdurrahman, M. 2003. Pendidikan Bagi Anak Berkesulitan Belajar. Jakarta: Rineka Cipta.

Ahmadi, A. \& W. Supriyono. 2013. Psikologi Belajar. Jakarta: Rineka Cipta.

Moleong, L.J. 2010. Metodologi Penelitian Kualitatif. Bandung: Remaja Rosdakarya. 
Hasratuddin. 2013. Membangun Karakter Melalui Pembelajaran Matematika. Jurnal Pendidikan Matematika PARADIKMA, 6 (2): 130-141.

Puspitasari, E., Edy, Y., Asep, N. 2015. Analisis Kesulitan Siswa dalam Menyelesaikan Soal Cerita Materi Sistem Persamaan Linear Dua Variabel di SMP. Jurnal Pendidikan dan Pembelajaran, 4 (5): 1-9

Sugiyono. 2013. Metode Penelitian Kuantitatif, Kualitatif, dan R\&D. Bandung: Alfabeta.

Susanto, A. 2013. Teori Belajar dan Pembelajaran di Sekolah Dasar. Jakarta: Prenadamedia Group.

Untari, E. 2013. Diagnosis Kesulitan Belajar Pokok Bahasan Pecahan pada Siswa Kelas V Sekolah Dasar. Jurnal Ilmiah STKIP PGRI Ngawi, 13 (1): 1-8 